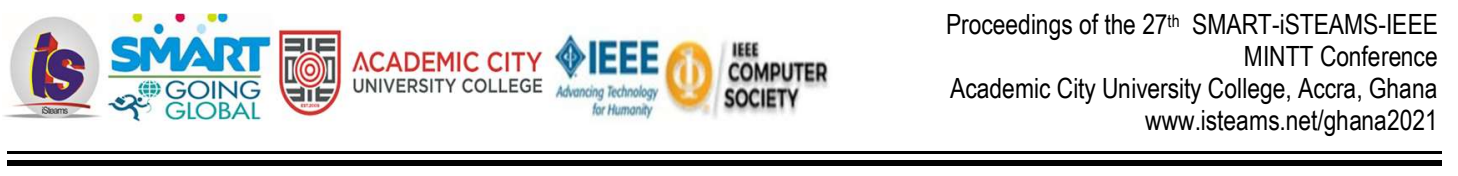

\title{
Impact of Board Gender and Diversity on Financial Reporting Quality of Deposit Money Banks (DMBS)
}

\author{
${ }^{1}$ Williams, B.M. \& ${ }^{2}$ Ogundele, S.A. \\ ${ }^{1}$ Department of Banking and Finance \\ 2Department iof Business Administration \\ Lagos State Polytechnic, Ikorodu, Nigeria \\ E-mail: williams.m@mylaspotech.edu.ng; aadebowaleshakur@gmail.com
}

Phone: +2348023202336; +2348129699868

\begin{abstract}
The continuous decline the financial reporting quality of Deposit Money Banks (DMBS) calls for urgent attention of researchers, this paper hereby examines the impact of board gender and diversity on financial reporting quality of Deposit Money Banks (DMBS). To achieve the objective of this study, the data for this study were mainly be from Secondary from NSE, in this study the researcher selected five (5) major top Deposit Money Banks for statistical evaluation. Panel Data Regression Analysis were employed in order to test the hypotheses of the study. The study revealed that Presence of Women on Board of Directors has positive $(0.003)$ but insignificant effect $(0.545)$ on the financial performance of firms under investigation; Gender mix has a positive $(0.063)$ but significant $(0.016)$ relationship with firm financial performance of listed banks in Nigeria; proportion of women in boards has a positive (0.002) but insignificant (0.999) effect on firm financial performance of companies investigated, and Finally, it was found that Board Gender Diversity has a positive $(0.129)$ with an insignificant effect $(0.399)$ on firm financial performance of listed Deposit Money Banks in Nigeria. Arisen from the findings of the study, the study recommended that firms should encourage the independence of audit committees in their firms, this may significantly improve their financial performance; management of firms are encouraged to make use of economic policies that would enhance the financial performance of the firm; companies should hold an optimal number of board members that the company can effectively manage bearing in mind that the higher the number of board members the more difficult it is to make quick decisions. On the contrary a decision taken by few members may be subject to bias; and firms are encouraged to use auditors with high experience and technical competence to audit their firms.
\end{abstract}

Keywords: Board Gender, Diversity, Financial Reporting Quality, Deposit Money Banks (DMBS)

Proceedings ReferenceFormat

Williams, B.M. \& Ogundele, S.A. (2021): Impact of Board Gender and Diversity on Financial Reporting Quality of Deposit Money Banks (DMBS).

Proceedings of the 27th iSTEAMS Multidisciplinary Innovations \& Technology Transfer (MINTT) Conference.Academic City University College, Accra, Ghana. June, 2021. Pp 113- 124 www.isteams.net/ghana2021.

DOI - https://doi.org/ 10.22624/AIMS/iSTEAMS-2021/N27P11

\section{INTRODUCTION}

Financial reporting quality continues to improve earning management which has dominated the literature of accounting since the spectacular financial scandals affecting major global financial and non-financial institution some of which include, Enron Corporation, Tyco, A. P., Xerox, Health South and World com in 


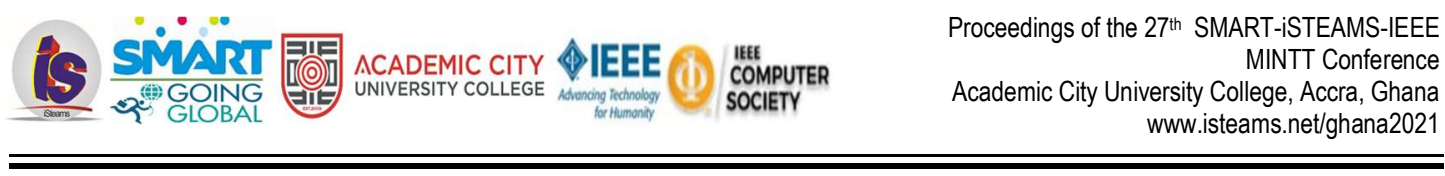

the U.S, Adelphia Intercontinental bank Nigeria among others (Akingunola, Adekunle, \& Adedipe, 2018; Isa \& Farouk, 2019). These were achieved by enhancing the performance through increasing operations and improving delivery with the aim of maintaining gender equality in to operations by 2020 . The efforts of the economics reeling in financial distress, thus, attracting the mind of many practitioners, the regulators and other researchers to finding the possible solution in corporate businesses has become somewhat a cliché. However, enthroning the fundamental objective of financial reporting which encompass tendering quality financial information concerning Deposit Money Banks as well as enhancing effective reports influence stakeholders in making resource allocation decisions (Jasmin, Kenstin, \& Karin, 2018). Financial reporting quality is a subjective evaluation of the extent which the financial report is free of manipulation and accurately reflects the financial conditions and operating success of a business concern. There are four important indicators of financial reporting quality: likehood of meeting, earnings forecasts, the probability of a financial statement misstatement and the likelihood of an internal control weakness (Kolhari, 2019).

It is important to be aware, however, that quality of information in final report including disclosures in notes. High quality reporting provides decision useful information which is relevant to Deposit Money Banks that leads to realities during the reporting period as well as the financial condition at the end of the year or period (Paul, \& David, 2007).

\subsection{Statement of the Problem}

Studies on board diversity and financial reporting quality has obviously seen in practice by Nigerian Deposit Money Banks, does not represent international best practice policies. The problem of financial reporting disclosure is the non-compliance to the bank, government, ethics and a regulatory standard which is prudent in the Deposit Money Banks of Nigeria. Due to the varying nature of board (Gender) diversity practices in different countries of the world, these may be large variation on its practice resulting in lack of uniformity in terms of board gender composition of these industries (Peni, \& Vahamaa, 2010).

Given that, the existence of literature as well as research on board gender diversity and financial reporting quality from Nigerian dimension in view of the fact that most previous studies have been analysed from a western outlook, it challenges the objective of investigating board gender and financial reporting quality from a Nigerian perspective, as the models/conceptual frame work develop in the advanced economies cannot be easily adopted in the case of African especially Nigeria. This may suggest that board gender and financial reporting quality may be at its elementary state in Nigeria. Board Gender diversity on financial reporting quality examines how female passed good information in other to enhance financial reporting quality.

\subsection{Research Objectives}

The objective of this research is to empirically investigate the impact of board gender and diversity on financial reporting quality of Deposit Money Banks (DMBs).

Specifically, this study seeks to:

1. To ascertain whether gender mix has significant impact on financial reporting quality.

2. To ascertain the presence of women in boards and financial reporting quality

3. To determine the relationship between presence of women in board and financial reporting quality. 


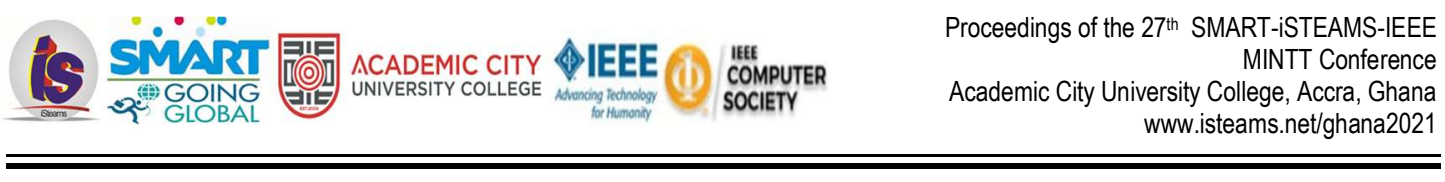

\subsection{Research Hypotheses}

The following are the hypotheses of this study state in null form:

\section{Hypothesis One}

$H_{01}$ : Gender mix has no significant effect on financial reporting quality.

\section{Hypotheses Two}

$\mathrm{H}_{02}$ : There is no significant relationship between the presence of women in Boards and financial reporting quality.

\section{Hypotheses Three}

$\mathrm{H}_{03}$ : There is no significant relationship between the proportion of women in Board's index and financial reporting quality.

\subsection{Scope of the Study}

The researcher tried to search light on the Deposit Money Banks in order to reveal any potential benefit that will enhance quality reporting, and the period of the proposed study was from 2004 to 2019 which will enable the researcher to get current information that will improve quality reporting.

\section{LITERATURE REVIEW}

\subsection{Concept of Financial Reporting Quality}

Ideally analysts would always have access to financial reports that are based on sound financial reporting standards, such as those from the International Accounting Standards Board (IASB) and the Financial Accounting Standard Board (FASB). and are free from manipulation. But, in practice, the quality of financial reports can vary greatly. High-quality financial reporting provides information that is useful to analysts in assessing a Deposit Money Banks performance and prospects (Omoye, \& Eriki, 2015). Financial reporting quality relates to the exactitude with which a company's reported financial statements mirrors the operating performance and to their usefulness for forecasting future cash flows. They further observed that higher quality of financial reports facilitates better understanding of the past and better prediction of the future.

According to Daske and Genhardt (2006) assessing financial reporting quality unavoidably includes preferences among a myriad of constituents. Different user groups of financial reports have divergent preferences, consequently, perceived quality will deviate among constituents. As a result of this, measuring quality directing seems to be a problem. Due to this position quality of financial reporting has been measured by many focusing on attribute's that influence quality of financial reports such as financial restatement, material weakness in internal control, probability of beating or meeting the analysts' expectations, and actual quality. Financial reporting is a key ingredient required for the corporate governance system to function successfully (Omoye, \& Eriki, 2015).

\subsection{Overview of Deposit Money Banks in Nigeria}

According to Cecilia, and Zachary (2018), Deposit Money Banks whose duty is to ensure that customers money is saved and to provide sufficient services which will enable customer to make transaction without encountering of network problems. Deposit Money Banks are financial institutions that provide services, such as accepting deposits, giving business loans and auto loans, mortgage lending and basic investment 


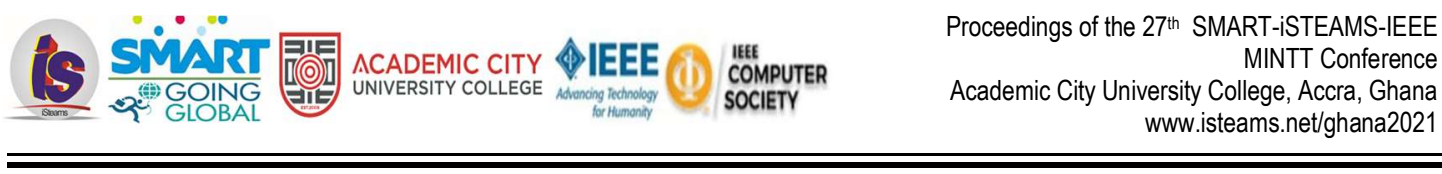

products like savings mobilization and financial resources allocation institutions. Consequently, their roles make them an important phenomenon and strong pillar in economic growth and development. They provide the foundation for the development of financial system. Their credit components constitutes a major link between the monetary sector and the real sector of the Nigerian economy, in performing these roles, Deposit Money Banks must realize that they have the potentials scope and prospects of mobilizing financial resources and allocating them to productive investments and in return, promote sustainable performance and ensure that business are flourishing they are not only store our saved cash and land us money when we need it, but act as the system of arteries that transport money around the economy, that is why they are often known as financial intermediaries (Cohen, Krishnamoorthy \& Wright, 2019).

\subsection{Board Structure of Deposit Money Banks in Nigeria.}

According to Garret, Hoitash, and Prawitthh, (2015), following the growing concerns about unethical practices in the Nigerian Deposit Money Banks which are capable of eroding public confidence in the industry, the governor of the central bank of Nigeria (CBN) articulated the urgent need for Deposit Money Banks to take steps to combat the emerging menace. In line with the provisions of the applicable laws, the governor sought the co-operation of banks through the bankers committee which are as follows:

i. The board statutory audit committee: this committee is responsible for ensuring that the bank complies with all the relevant policies and procedures both from the regulators and as land-down by the board of directors.

ii. The board risk management committee: this committee provide oversight of management's activities in managing credit, market, liquidity, operational, legal and other risks of the institution.

iii. The board governance and remuneration committee: the role of this committee is to ensure a good governance in Deposit Money Bank.

iv. The board credit and finance committee: the committee is responsible for approval of credit facilities in the bank.

v. Committee on information request: if the deposit insurer requests certain information is the committee that will attained to them.

\subsection{Board Diversity}

Diversity is any dimension that can be used to differentiate groups and people from one another. It's about empowering people by respecting and appreciating what makes them different, in terms of age, gender, ethnicity, religion and disability. Generally, diversity refers to policies and practices that seek to include people, who are considered in some way, different from traditional members. Traditional members are people from similar backgrounds in terms of race or gender, in their study to understand the effects of diversity in organizational groups. We made to understand that Hafsi, and Turgut (2018)analyse diversity into observable (demographic) and non - observable (cognitive) dimensions. (Jasmin, Kenstin, \& Karin, 2018). Demographic dimensions include age, race and gender; and cognitive dimensions.

It implies to conceptualization, processing of information, applying knowledge, changing preferences, socioeconomic ground, and personality characteristics. (Kolhari, 2019)most companies recognized the importance of making diversity a business imperative, it is often not a top business priority (Mingues, Mingues, \& Lucas-Peres, 2017). Other business initiatives that present more compelling factual evidence of return on investment, take precedence over diversity initiatives (Paul, \& David, 2007).Yinka, Salaudeen, and Emmanuel, (2003)conducted a literature review to build a business case for diversity with a focus on workplace diversity in terms of race, age and gender. 


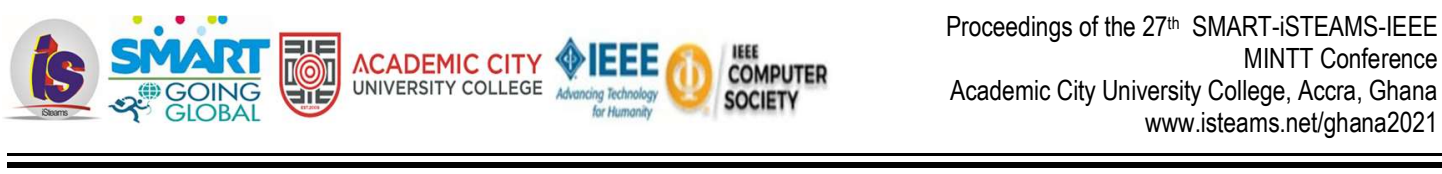

In their work, they identified, explained and update the competitive and business reasons for managing diversity. They identified cost savings as one of the reasons for managing diversity. When diversity is not noticeable in top positions there is practically no one that serves as a model for aspirant diverse workforce. The perceived lack of opportunity for career growth is the primary reason professional and managerial woman leave their works and this led to increases in costs due to selection and training of new staff.

Differences between men and women could indicate that the growing tendency of female directors on corporate boards may have a considerable influence on firms' decision-making process (Garret, Hoitash, \& Prawitthh, 2015). Female board members have better attendance records than male directors and that female board members are more likely to joint monitoring committees such as the audit committee or the compensation committee; their presence results in higher disclosure quality. Gender diverse boards are associated with higher quality sustainability reports and independent female directors have greater effect on sustainability reporting quality than male directors.

Female board members disclose more sustainability information of higher quality and have a better image regarding sustainable performance(Renee, Adams, Benjamin, \& Weisbach, 2010).Mary, Mindak, and Sen (2016)has found that organizations with a higher percentage of female board members disclose more sustainability information. Women can reduce the risk of insufficient capital in banking industry meanwhile, gender diversity in the board of directors is an important factor in the scope and quality of sustainability report.

The literature on gender diversity has found significant differences in behavioural characteristics of men and women which suggests that females make better monitors, more risk averse and less overconfident. As a result, board gender diversity has become an issue for discussion because of four benefits that a firm tends to gain when having a more gender diverse board, which are: improving financial performance; opportunities to attract a wider pool of talent; becoming more respective to the market; and finally, the ability to strengthen its corporate governance policies (Kolhari, 2019).

Cohen, Krishnamoorthy, and Wright, (2019) suggested that, the heterogeneity in decision-making by the corporate boards helps, to solve problems and enhances the presence of better decision-making because the board can engage in the critical analysis of issues. Besides, are women less risk tolerant, than men during an investment decision. Firms can therefore balance their risk making.

\subsection{Theoretical Review}

\subsubsection{Critical Mass Theory}

Preceding the account on behaviour between genders in a boardroom setting are expected in this study, this section focused on the notion of a "critical mass" as introduced by Garret, Hoitash, and Prawitthh, (2015). Critical mass theory proposed by Garret, Hoitash, and Prawitthh, (2015). It states that, with the help of a hand-collected panel dataset of 151 listed German firms for the years 2000-2005, the theory explores whether the link between gender diversity to at first negatively affect firm's performance and only after a "critical mass" if about $30 \%$ women has been reached to be associated with higher firm performance than completely make boards. In line with the sample firms, the critical mass of $30 \%$ women translates in to an absolute number of about three women on the board and hence supports recent studies on a corresponding "magic number" of women in the boardroom. In addition to the theory in concise inclusion of woman in the boardroom in other to have a good financial reporting quality on Deposit Money Banks. 


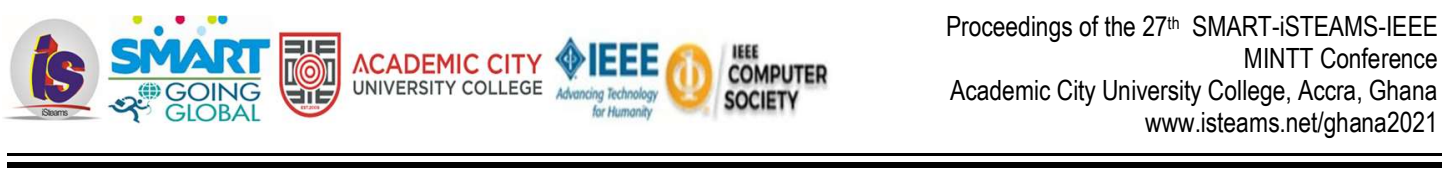

Female directors in the Board of Directors (BOD) of Deposit Money Banks (DMB) are unable to effect any change unless the quality reaches a threshold, we find evidence for gender diversity to at first negatively affect firm performance and only after a "critical mass" of about 301. Women translates into an absolute number of about three women directors, the board also needs to have a critical mass of women for them to make real impact on the firm. For women to fully feel comfortable in exerting their different characteristics, a critical mass conditionmust be met (Cecilia, \& Zachary, 2018). For women to feel comfortable with exerting their unique behaviour and opinions in a board room, they need to be surrounded by a minimum number of likeminded individuals (in this case other women) (Omoye, \& Eriki, 2015).

\subsubsection{Agency Theory}

This theoretical aspect aimed to explore the main ideas and perspectives in which women are more likely to align with the independence characteristic recommended by corporate governance codes. The presence of women on director boards increases the quantity and quality of public disclosure by firms. As a result, a great number of studies have analysed the impact of female presence on corporate boards on different aspects of management such as decision-making (Adamu, \& Zango, 2016). Adamu and Zango, (2016)findings suggest that women are more likely to joint committee that have monitoring functions, such as audit, and corporate governance committees, which are directly involved in increasing transparency (Barau, 2010). In Bhattacherjee (2012),the importance of the form of executive compensation in mitigating asymmetric information. They find that compensation packages that reward managerial performance reduce asymmetric information, because the executives are encouraged to reveal the level of effort, they expend in order to qualify for performance payments.

\section{METHODOLOGY}

The data for this study were mainly be from Secondary. The relationship between these data were also evaluated to enable the researcher have a clear understanding of the associations between the dependent variables and the independent variables. The study adopts a positivist philosophy as it utilizes quantitative data for its analysis.

\subsection{Population of Study}

Population of study forms the subject matter of the study in a particular survey, the population shall comprise 18 Deposit Money Banks (DMBs) (NSE) (Factbook, 2019) whose shares are publicly traded on the electronic trading platform of the Nigeria Stock Exchange (NSE). The sample of the population were randomly selected from population of Deposit Money Banks listed on NSE from 2004 to 2019. The period selected takes into consideration the regulation of the central Bank of Nigeria instructing Deposit Money Banks to prepare their financial year accounts to $31^{\text {st }}$ December of each year.

\subsection{Sample Size and Sampling Technique}

Sample size is a number of sample units (fewer than the aggregate) drawn from a population. In this study the researcher selected five (5) major top Deposit Money Banks for statistical evaluation.

\subsection{Method of Data Analysis}

The data once collected wereanalysed using descriptive and inferential statistics. Descriptive statistics were employed to provide background statistical information of the data. In testing hypotheses one, two and three, Panel Data Regression Analysis were employed in order to test the impact of board gender diversity on 


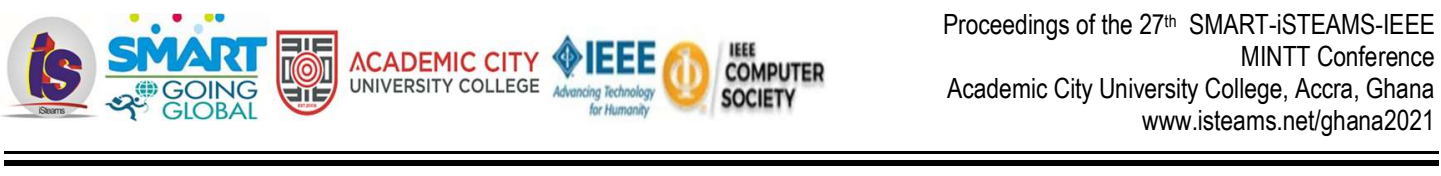

financial reporting quality on Deposit Money Banks (DMBs) in Nigeria. All the components of Regression Analysis as a method of testing all three hypotheses of this study are the Coefficient of Determination $\left(R^{2}\right)$. the adjusted $\mathrm{R}^{2}$, Standard Deviation Error, T-statistic and F- statistic.

\section{DATA ANALYSIS AND INTERPRETATION}

\subsection{Variance inflation factor (VIF)}

Table 1 below revealed that the average VIF obtained from the regression result is 1.76 which is above the bench mark of 1, to be specific the VIF of Presence of Women on Board of Directors is 2.59, that of proportion of women in boards is 1.70 , Board Gender Diversity is 1.44 , Gender mix is 1.20 and Financial Reporting Quality is 1.13 the mean VIF of the model is less than 5 . This clearly indicates the absence of multicollinearity problem among the independent variables under investigation; multicollinearity is a situation where the independent variables are correlated such that their individual effect on the dependent variable cannot be clearly identified. This technique ensures that the independent variables are not so correlated to the point of distorting the results and assists in filtering out those ones which are likely to obstruct the robustness of the model.

Table 1: Variance Inflation Factor (VIF)

\begin{tabular}{|l|l|l|}
\hline Variable & VIF & $\mathbf{1}$ VIF \\
\hline Presence of Women on Board of Directors & 2.59 & 0.386798 \\
\hline Financial Reporting Quality & 1.13 & 0.884376 \\
\hline proportion of women in boards & 1.70 & 0.587600 \\
\hline Board Gender Diversity & 1.44 & 0.694053 \\
\hline Gender mix & 1.20 & 0.831177 \\
\hline Mean VIF & 1.76 & \\
\hline
\end{tabular}

\section{Source: STATA version 14}

Table 1 also show that the tolerance value (TV) for all the variables is above 0 and close to 1 which falls within the recommended range for regression analysis; these results are pointers to the fact that there is absence of multicollinearity problem among the independent variables.

\subsection{Lagrange multiplier (LM) test}

The Breusch-Pagan Lagrange Multiplier is a test that helps the researcher to decide between the random effect (RE) regression and the simple time series ordinarily list square (OLS) regression techniques for the analysis of data. The null hypothesis in the LM test is that variance across entities (panels) is zero implying that there is no panel effect in the data therefore; one can run a simple OLS. The decision rule is that if the prob>chi2 is less than 0.05 the null hypothesis is rejected otherwise accepted. In this study, the LM test show the prob>chi2 of 0.414 which proves evidence of insignificant differences across panels thus the null hypothesis is accepted meaning that the OLS simple time series regression is a more appropriate technique against the random effect model. 
4.3 Data Analysis

Table 2:Correlation statistics

\begin{tabular}{|c|c|c|c|c|c|}
\hline & $\begin{array}{c}\text { Financial } \\
\text { Reporting } \\
\text { Quality }\end{array}$ & $\begin{array}{c}\text { Presence of Women } \\
\text { on Board of } \\
\text { Directors }\end{array}$ & $\begin{array}{l}\text { Gender } \\
\text { mix }\end{array}$ & $\begin{array}{l}\text { proportion of } \\
\text { women in } \\
\text { boards }\end{array}$ & $\begin{array}{c}\text { Board } \\
\text { Gender } \\
\text { Diversity }\end{array}$ \\
\hline $\begin{array}{l}\text { Financial Reporting } \\
\text { Quality }\end{array}$ & 1.0000 & & & & \\
\hline $\begin{array}{l}\text { Presence of Women on } \\
\text { Board of Directors }\end{array}$ & -0.0766 & 1.0000 & & & \\
\hline Gender mix & 0.2401 & 0.0413 & 1.0000 & & \\
\hline $\begin{array}{l}\text { proportion of women in } \\
\text { boards }\end{array}$ & 0.0936 & -0.5147 & -0.0632 & 1.0000 & \\
\hline Board Gender Diversity & 0.1331 & -0.3305 & 0.2660 & -0.0363 & 1.0000 \\
\hline
\end{tabular}

\section{Source: STATA version 14 output}

From Table 2 above, the highest correlation is between Board Gender Diversity and Gender mix which is 0.266 , this figure is considered appropriate for the use of regression analyses. The highest value of correlation among the predictor variables is relatively appropriate, this connotes that the independent variables are related in such a way that their individual effect on the outcome variables can clearly be distinguished implying that there is absence of multicollinearity problem.

\subsection{Test of Hypotheses}

Hypothesis One

$\mathrm{H}_{0}$ : Gender mix do not have significant effect on financial reporting quality

Regression model was employed for the analysis

Decision criterion is to accept $\mathrm{H} 0$ : if $p$ value is lower than 0.05 level of significance.

\section{Model Summary}

\begin{tabular}{|l|r|r|r|r|r|}
\hline Model & $\mathrm{R}$ & R Square & Adjusted R Square & $\begin{array}{c}\text { Std. Error of the } \\
\text { Estimate }\end{array}$ & Durbin-Watson \\
\hline 1 & $.721 \mathrm{a}$ & .677 & .525 & 85474100154.5414 & 2.51 \\
\hline
\end{tabular}

a. Predictors: (Constant).Gender mix

b. Dependent Variable: Financial reporting quality

Source: SPSS version 25 output.

Coefficients

\begin{tabular}{|c|c|c|c|c|c|}
\hline \multirow[b]{2}{*}{ Model } & \multicolumn{2}{|c|}{ Unstandardized Coefficients } & $\begin{array}{l}\text { Standardized } \\
\text { Coefficients }\end{array}$ & & \\
\hline & $B$ & Std. Error & Beta & $t$ & Sig. \\
\hline (Constant) & 541416329 & 41023109 & & 2.210 & .001 \\
\hline Gender mix & 4.141 & 3.210 & .671 & 3.21 & .009 \\
\hline
\end{tabular}

a. Dependent Variable: Financial reporting quality

Source: SPSS version 25 output. 
$\mathrm{R}$ Sqaure explain the relationship between variable. As shown in the model summary, there is positive relationship between Gender mix and financial reporting quality, and this account for about $67 \%$. $R$ being the determinant of correlation explain the extent to which the independent variable could explain the dependent variable. R square as shown in model summary is about $72 \%$, this implies that the independent variables can predict or determine dependent variables up to $72 \%$. This simply means that Gender mix can determine changes in financial reporting quality up to about $72 \%$. This study revealed that a unit change in Gender mix account for about 4.1positive unit change in financial reporting quality. This study revealed that Gender mix have a significant positive effect financial reporting quality.

\section{Decision}

The $p$ value of 0.009 is lower than 0.05 , we hereby conclude that Gender mix have significant effect on financial reporting quality, and hereby reject the null hypothesis.

\section{Hypothesis Two}

$\mathrm{Ho}_{2}$ : There is no significant relationship between the presence of women in Boards and financial reporting quality.

Regression model was employed for the analysis

Decision criterion is to accept $\mathrm{HO}$ : if $p$ value is lower than 0.05 level of significance.

\section{Model Summary}

\begin{tabular}{|l|c|r|r|r|r|}
\hline Model & R & R Square & Adjusted R Square & Std. Error of the Estimate & Durbin-Watson \\
\hline 1 & $.518 \mathrm{a}$ & .471 & .495 & 77414100154.5414 & 1.51 \\
\hline
\end{tabular}

a. Predictors: (Constant). presence of women in Boards

b. Dependent Variable: financial reporting quality

Source: SPSS version 25 output.

\section{Coefficients}

\begin{tabular}{|c|c|c|c|c|c|}
\hline \multirow[b]{2}{*}{ Model } & \multicolumn{2}{|c|}{ Unstandardized Coefficients } & $\begin{array}{c}\text { Standardized } \\
\text { Coefficients }\end{array}$ & \multirow[b]{2}{*}{$t$} & \multirow[b]{2}{*}{ Sig. } \\
\hline & $B$ & Std. Error & Beta & & \\
\hline 1 (Constant) & 641416329 & 41003109 & & 1.210 & .011 \\
\hline $\begin{array}{l}\text { Presence of women } \\
\text { in Boards }\end{array}$ & 3.141 & 2.210 & .411 & 3.21 & .001 \\
\hline
\end{tabular}

a. Dependent Variable: financial reporting quality

Source: SPSS version 25 output.

There is positive relationship between presence of women in Boards and financial reporting quality, and this account for about $47 \%$. R being the determinant of correlation explain the extent to which the independent variable could explain the dependent variable. $R$ square as shown in model summary is about $51 \%$, this implies that the independent variables can predict or determine dependent variables up to $51 \%$. This simply means that presence of women in Boards can determine changes in financial reporting quality up to about $51 \%$. This study revealed that a unit change in presence of women in Board's account for about 3.14 positive unit change in financial reporting quality. This study revealed that presence of women in Boards significantly affect financial reporting qualitypositively. 


\section{Decision}

The $p$ value of 0.001 is lower than 0.05 , we hereby conclude that there is significant relationship between the presence of women in Boards and financial reporting quality, and hereby reject the null hypothesis.

\section{Hypothesis Three}

$\mathrm{Ho}_{3:} \quad$ There is no significant relationship between the proportion of women in Board's index and financial reporting quality.

Model Summary

\begin{tabular}{|l|r|r|r|r|r|}
\hline Model & $\mathrm{R}$ & R Square & Adjusted R Square & $\begin{array}{c}\text { Std. Error of the } \\
\text { Estimate }\end{array}$ & Durbin-Watson \\
\hline 1 & $.217 \mathrm{a}$ & .277 & .525 & 14741100154.5414 & 2.01 \\
\hline
\end{tabular}

a. Predictors: (Constant). proportion of women in Board's index

b. Dependent Variable: financial reporting quality

Source: SPSS version 25 output.

\section{Coefficients}

\begin{tabular}{|c|c|c|c|c|c|}
\hline \multirow[b]{2}{*}{ Model } & \multicolumn{2}{|c|}{ Unstandardized Coefficients } & $\begin{array}{l}\text { Standardized } \\
\text { Coefficients }\end{array}$ & \multirow[b]{2}{*}{$t$} & \multirow[b]{2}{*}{ Sig. } \\
\hline & $B$ & Std. Error & Beta & & \\
\hline 1 (Constant) & 714116329 & 14123109 & & 1.210 & .001 \\
\hline $\begin{array}{l}\text { proportion of women in } \\
\text { Boards index }\end{array}$ & 1.141 & 1.210 & .071 & 2.21 & .009 \\
\hline
\end{tabular}

a. Dependent Variable: financial reporting quality

Source: SPSS version 25 output.

As shown in the model summary, there is positive relationship between proportion of women in Boards index and financial reporting quality, which account for about $27 \%$. R being the determinant of correlation explain the extent to which the independent variable could explain the dependent variable. $R$ square as shown in model summary is about $21 \%$, this implies that the independent variables can predict or determine dependent variables up to $21 \%$. This simply means that the proportion of women in Board's index can determine financial reporting quality is about $21 \%$. This study revealed that a unit increase in proportion of women in Board's index account for a significant decrease in financial reporting quality. This study revealed that proportion of women in Board's index have a significant effect on financial reporting quality.

\section{Decision}

The $p$ value of 0.009 is lower than 0.05 , we hereby conclude that there is significant relationship between the proportion of women in Boards index and financial reporting quality., and hereby reject the null hypothesis. 


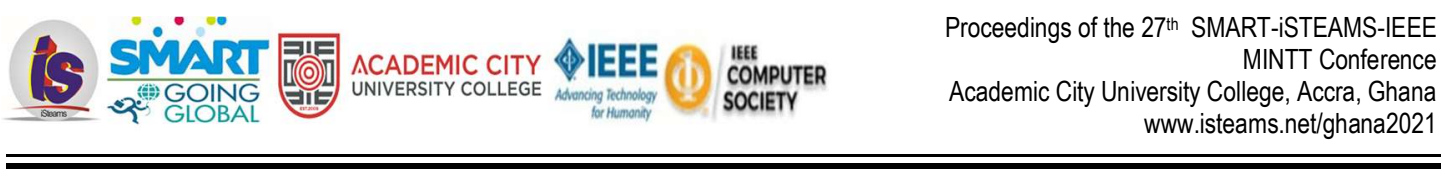

\section{SUMMARY OF FINDINGS}

The test of hypotheses shows mixed findings as some of the predictor variables show positive association while others show positive associations.

The study revealed that gender mix has significant effect on financial reporting quality; there is significant relationship between the presence of women in Boards and financial reporting quality; there is significant relationship between the proportion of women in Board's index and financial reporting quality.

The study revealed the following findings:

1. It was discovered that Presence of Women on Board of Directors has positive $(0.003)$ but insignificant effect $(0.545)$ on the financial performance of firms under investigation.

2. It was found that Gender mix has a positive $(0.063)$ but significant $(0.016)$ relationship with firm financial performance of listed banks in Nigeria

3. It was also found that proportion of women in boards has a positive (0.002) but insignificant (0.999) effect on firm financial performance of companies investigated.

4. Finally, it was found that Board Gender Diversity has a positive (0.129) with an insignificant effect (0.399) on firm financial performance of listed Deposit Money Banks in Nigeria.

\section{CONCLUSION}

The results demonstrated that a positive and significant association exist between board gender diversity on financial reporting quality in Nigeria, hence; Presence of Women on Board of Directors and proportion of women in boards demonstrated a positive and significant relationship with the financial performance of firms under investigation. However, Gender mix associated positive and significant with firm financial performance. Furthermore, Board Gender Diversity has a positive relationship and significant effect on firm financial performance. Based on the findings above it is incorrect to assert that board gender diversity does not affect financial reporting quality in Nigeria. Generally, this study concludes that, board gender diversity on financial reporting quality in Nigeria.

\section{RECOMMENDATIONS}

1. Presence of Women on Board of Directors has a positive but insignificant relationship with firm financial performance. It is recommended that firms under investigation should encourage the independence of audit committees in their firms; this may significantly improve their financial performance.

2. Gender mix has positive but significant effect on the financial performance of firms investigated. Therefore, the managementfirms investigated are encouraged to make use of economic policies that would enhance the financial performance of the firm.

3. Board size is insignificant to firm financial performance. It is recommended that companies should hold an optimal number of board members that the company can effectively manage bearing in mind that the higher the number of board members the more difficult it is to make quick decisions. On the contrary a decision taken by few members may be subject to bias.

4. Board Gender Diversity is positive but insignificant to firm performance of listed Deposit Money Banks in Nigeria.Firms investigated are encouraged to use auditors with high experience and technical competence to audit their firms. 


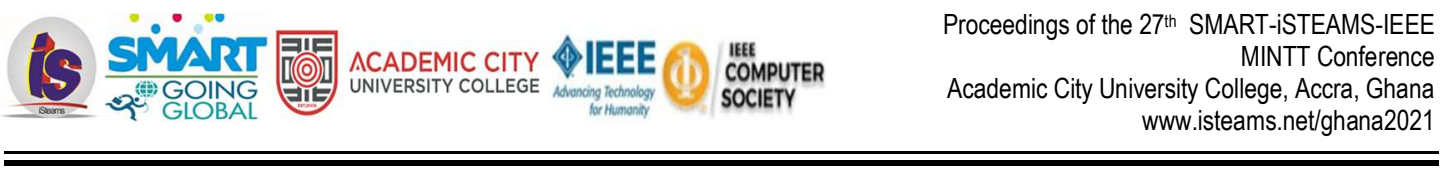

\section{REFERENCES}

1. Akingunola, R. (2018). Corporate Governance and Bank Performance in Nigeria (Post Banks' Consolidation).European Journal of Business and Social Sciences, 2(8), 89-111.

2. Adamu, G., \&Zango, H. (2016). Audit Quality, board gender and financial risk disclosure. Journal of Management Sciences, 4(2), 14 - 27.

3. Barau A. (2010).CFO Gender and accruals quality accounting Horizons. New York: AAA Digital Library.

4. Bhattacherjee A (2012). Social science research: Principles, methods, and practices. $2^{\text {nd }}$ ed. Maryland: Open Textbooks.

5. Omoye, I., \& Eriki, O. (2015). Board leadership structure and earnings Quality: Evidence from Quoted manufacturing firms in Nigeria. Journal of Management Sciences, 12(9), 61 - 97.

6. Cecilia, M. P.,\& Zachary, B.A. (2018).Top management team diversity quality of commercial bank. Journal of Management Sciences, 5(4), $55-67$.

7. Cohen, J., Krishnamoorthy, G., \& Wright, A. (2019). The Corporate Governance Mosaic and Financial Reporting quality.Journal of Social Sciences, 7(1), $134-141$.

8. Garret, J., Hoitash, R.,\& Prawitthh, D. F. (2015). Trust and Financial Reporting Quality. Journal of Accounting Research, 52(5). 107 - 125.

9. Hafsi, T., \& Turgut, G. (2018). Boardroom Diversity and its effect on social performance: conventionalization and empirical evidence.Journal of Business Ethics, 112(3), 463-479.

10. Isa, A., \& Farouk, M.A. (2019). A Study of the effect of Diversity in the Board and the Audit Committee. Journal of Accounting, finance and Auditing Studies, 4(1), 14-39.

11. Jasmin, J., Kenstin, P., \& Karin, V. (2018).Gender Diversity in the Boardroom and Firm performance: Journal of Boardroom and Firm Performance: Journal of Business Ethics, 118(1),6172.

12. Kolhari, C. R. (2019).Research methodology: methods and techniques (2nd edition).New York: New age International publishers.

13. Mary, P., Mindak, P.K.,\&Sen, J.S (2016). Beating Threshold targets with earnings management. Review of Accounting and finance Journal, 9(4), 16 - 24.

14. Mingues, A., Mingues, V.,\& Lucas-Peres. (2017).Does Gender diversity on corporate boards reduces information asymmetry? Vera: Lucas-Peres.

15. Paul, H., \&David, N. (2007).The use of unsigned earnings quality measures in taste of earnings management. Review of Accounting and finance Journal, 9(4), 141 - 152.

16. Peni, R. \& Vahamaa, S. (2010) Female executive and earning management. Management Finance Journal, 36(7), 629-645

17. Renee, B., Adams, B., Benjamin, E., \&Weisbach, M. (2010). The role of Board of Directors in Corporate Governance: A Conceptual Framework and Survey. Journal of Economic Literature.

18. Yinka, M., Salaudeen, J.B.,\& Emmanuel, I.B.(2003). Unethical Accounting practice and financial reporting quality.Journal of Accounting and finance, 2(2), $17-21$. 